\title{
A CONSORTIUM OF PLANT GROWTH-PROMOTING RHIZOBACTERIA STRAINS SYNERGISTICALLY ASSISTS JUJUNCAO (PENNISETUM GIGANTEUM) TO REMEDIATE CADMIUM CONTAMINATED SOILS
}

\author{
YANKEY, R. ${ }^{1}-$ KARANJA, J. K. ${ }^{2}-$ OKAL, E. J. ${ }^{1}-$ OMOOR, I. N. A. ${ }^{1}-$ LIN, H. ${ }^{1}-$ \\ BodJREMOU, D. M. ${ }^{3}-\mathrm{LI}, \mathrm{J} .{ }^{1}-\mathrm{LIN}, \mathrm{D} . \mathrm{M}^{1}{ }^{1}-\mathrm{CAO}, \mathrm{X} . \mathrm{M} .{ }^{1}-\mathrm{LIN}, \mathrm{Z} . \mathrm{X} .{ }^{{ }^{*}}$ \\ ${ }^{1}$ China National Engineering Research Center of Juncao Technology, College of Life Sciences, \\ Fujian Agriculture and Forestry University, Fuzhou, Fujian 350002, China \\ ${ }^{2}$ Center for Plant Water-Use and Nutrition Regulation, Joint International Research Laboratory \\ of Water and Nutrient in Crops, Fujian Agriculture and Forestry University, Fuzhou, Fujian \\ 350002, China \\ ${ }^{3}$ Institute of Horticultural Biotechnology, College of Horticulture, Fujian Agriculture and \\ Forestry University, Fuzhou, Fujian 350002, China \\ *Corresponding author \\ e-mail: lzxjuncao@163.com
}

(Received $4^{\text {th }}$ Jan 2021; accepted $18^{\text {th }}$ Mar 2021)

\begin{abstract}
Plant growth-promoting bacteria (PGPB) have received much attention in recent years due to their ability to interact with plants and remediate contaminated soil. This research aimed to assess the potential synergistic effect of three rhizobacterium strains; Enterobacter cloacae RCB980 (A3), Klebsiella pneumonia kpa (A4), and Klebsiella sp XT-2 (A7) in the remediation of cadmium (Cd) contaminated soils using Pennisetum giganteum plant. $P$. giganteum seedlings were transplanted into pots with seven different concentrations of $\mathrm{Cd}(0,25,50,75,100,150$, and $200 \mathrm{mg} / \mathrm{kg})$, and the rhizosphere treated with combinations of bacteria A3, A4, and A7, for 60 days. Plant height, shoot and root biomass, chlorophyll content, bioaccumulation (BAF) and translocation factors (TF) were then determined. Root and shoot BAF for plants inoculated with bacteria strains at soil Cd concentrations of 25 and $50 \mathrm{mg} / \mathrm{kg}$ were all above 1.0 whereas TF values were greater than 1.0 only at $25 \mathrm{mg} / \mathrm{kg} \mathrm{Cd}$ concentration. The study revealed that the application of double and triple strain consortium of bacteria significantly enhanced plant growth parameters and phytoremediation as compared to single strain. These results suggested that the strains had the synergistic potential to be utilized in enhancing $P$. giganteum growth and phytoremediation of Cd stressed soils.
\end{abstract}

Keywords: phytoremediation, heavy metals, chlorophyll, bacteria, pollution

\section{Introduction}

In recent years, contamination of the environment by heavy metals has increased sharply as a result of increased industrialization and excessive population growth. This continuous release of heavy metal pollutants into the environment has become so alarming that, the past decade recorded yearly global figures of 22,000, 783,000, 939,000, and 1,350,000 metric tons for cadmium $(\mathrm{Cd})$, lead $(\mathrm{Pb})$, copper $(\mathrm{Cu})$, and zinc (Zn) respectively (Singh et al., 2003). This poses major environmental and human health problems worldwide. It has already been established that high concentrations of heavy metals in the soil affect the growth of plants and reduce agricultural productivity (Edelstein and Ben-Hur, 2018). The response of plants to heavy metals in soils differs. When most plants accumulate heavy metals into their tissues, cellular activities are 
negatively affected leading to retarded growth (Hall, 2002; Bücker-Neto et al., 2017). The common heavy metal pollutants are $\mathrm{Cd}, \mathrm{Pb}, \mathrm{Cu}, \mathrm{Hg}$, and $\mathrm{Zn}$ (He and $\mathrm{Yang}$, 2007), therefore complete removal of such metals is the only way to effectively treat them since they cannot be easily broken down into harmless products (Wu et al., 2018).

Although several methods, with varying degrees of success and cost, are employed to address heavy metal pollution, the use of green plants in association with plant-growth promoting rhizobacteria (PGPR) has been generally accepted to be highly productive (Saxena et al., 2019). The use of grasses is most encouraged as they grow faster in low nutrient soils and usually have dense root and shoot biomass. Microorganisms play several roles in soil-water-plant-pollution relationships. Their importance in the heavy metal phytoremediation process cannot be over-emphasized, as their ability to endure metal toxicity, and change metal species into less toxic and soluble forms for plant uptake while promoting plant growth leading to enhanced biomass even under stressed environments.

Many studies have shown that bacterial strains of Enterobacter and Klebsiella species exhibit physiological and genetic characteristics which significantly enhanced growth of various plants (McKenzie-Reynolds, 2018; Liu et al., 2018; Dhungana and Itoh, 2019). P. giganteum also known as Jujuncao in Chinese is a tall herbaceous grass that is hardy and grows quickly under poor soil conditions while producing high biomass. The grass is widely cultivated and used for ecological remediation, animal feeding, and for production of edible and medicinal mushrooms. Although heavy metal accumulation capacities of certain plants such as Brassica juncea, Helianthus annuus, and Zea mays have been extensively studied, their large scale use for phytoremediation is limited due to their low biomass (Cui et al., 2004; Turgut et al., 2004; Szabó and Fodor, 2006). Despite high biomass trees such as Salix sp and Populus sp being demonstrated by Liphadzi et al. (2003) and Vervaeke et al. (2003) to potentially be ideal for phytoextraction, such trees generally take a longer period of time to grow and are therefore not good candidates for phytoremediation. Grasses, however, have generally become a good fit for this purpose and Jujuncao in particular, has been identified as potential good phytoremediators because of its wide growth adaptability, fast growth, and extensive roots and shoot biomass (Hayat et al., 2020). It would thus be interesting to explore the synergistic plant growth promotion association between these PGPR and Jujuncao for phytoremediation.

The success of bacteria assisted phytoremediation differs depending on the levels of tolerance of the plant and bacteria to the heavy metal in question. For these concerns, the selection of plant and bacteria species for phytoremediation of heavy metals depends mainly on the tolerance capacity of the bacteria and plant to the heavy metal and the plants' biomass production capabilities (Rezania et al., 2016). Moreover, it has been established that multiple contaminations of the same soil by different heavy metals are common and because different bacteria employ different mechanisms for remediation activities, some authors stress that bioremediation of heavy metals would be more successful if a cocktail of bacterial strains is utilized rather than using a single strain culture (Kang et al., 2016; Varjani et al., 2020). Previous studies have reported the ability of Klebsiella $s p$ and Enterobacter $s p$ to tolerate high Cd concentrations and to promote plant growth in heavy metal contaminated soils (Pramanik et al., 2018; Chuanboon et al., 2019). Therefore, this research aims to study the synergistic effect of these strains in the remediation of Cd contaminated soils using $P$. giganteum plants. 


\section{Materials and Methods}

\section{Isolation of rhizobacteria strains}

Following a random harvesting of $20 \mathrm{P}$. giganteum plants from the Lianjiang abandoned copper mines, Lianjiang, Fujian province, China and their subsequent movement to the laboratory in zip lock bags, bacteria was isolated from the composite pool of rhizospheric soil attached to the roots of the plants using Davis Minigioli (DM) agar medium according to the procedure of Sarkar et al. (2018). High Cd tolerance was taken as preliminary screening criteria during the isolation of the PGPR using the plate technique screening method according to the procedure of Rajesh et al. (2014). Subsequently, three PGPR strains of the Klebsiella and Enterobacter species were selected, identified as Enterobacter cloacae RCB980, Klebsiella pneumonia kpa, and Klebsiella sp XT-2 and were subsequently tagged as A3, A4 and A7, respectively, for the study of their synergistic growth and phytoremediation potentials on P. giganteum. The BLAST sequences were submitted to NCBI and assigned Genbank accession numbers MT103318, MT103319, and MT103320, respectively.

\section{Soil preparation and pot experiment}

The experimental soil was collected from Minhou, Fuzhou city, Fujian province, China. The basic physicochemical properties of the soil were $\mathrm{pH} 6.5$, total organic carbon $16.3 \mathrm{~g} / \mathrm{kg}$, total nitrogen $1.2 \mathrm{~g} / \mathrm{kg}$, cation exchange capacity (CEC) $10.5 \mathrm{cmol} / \mathrm{kg}$, and total $\mathrm{Cd} 0.95 \mathrm{mg} / \mathrm{kg}$. The methods for determining the basic physicochemical properties of soils followed Tang et al. (1999). Soil total Cd was determined by ICP-MS (Agilent 7500a, USA) after digestion with $\mathrm{HNO}_{3}-\mathrm{HClO}_{4}-\mathrm{HF}$. Cuttings of $P$. giganteum were prepared and nursed at the Juncao experimental field and were grown in mini pots for one month before being transferred to the experimental pots (40 (diameter) x 40 (height) $\mathrm{cm}$ ) containing $9 \mathrm{~kg}$ of non-sterile field soil. The experiment was carried out in a greenhouse with a temperature range of 25 to $32^{\circ} \mathrm{C}$ and 50 to $80 \%$ relative humidity, while soil water content was maintained at $60 \%$ of water holding capacity.

The experiment employed a completely randomized design that had seven treatments of the three bacteria strains and their combinations; (A3, A4, A7, A3\&A4, A3\&A7, A4\&A7, A3\&A4\&A7); applied on P. giganteum in pots under seven concentrations of $\mathrm{Cd}(0,25,50,75,100,150$ and $200 \mathrm{mg} / \mathrm{kg})$ with three replicates each. Different concentrations of the Cd were prepared in distilled water, added to the soil in the pots, and mixed thoroughly. The control without $\mathrm{Cd}$ was mock-treated with the same amount of distilled water. The Cd contaminated soils and the controls were subsequently kept for 2 weeks for stabilization purpose before planting. $P$. giganteum plants of average height $(75 \mathrm{~cm})$ were then transplanted into the plastic pots with three replicates per treatment, resulting in a total of 168 pots. The three bacteria strains were cultured at $28^{\circ} \mathrm{C}$ for $48 \mathrm{~h}$ on Luria-Bertani (LB) agar medium. A single colony from a freshly streaked plate was selected, inoculated into LB broth, and incubated at $28^{\circ} \mathrm{C}$ for $48 \mathrm{~h}$ on a gyro-rotatory shaker at $200 \mathrm{rpm}$. For single strain treatment, $15 \mathrm{ml}$ of each bacterium culture containing $10^{6} \mathrm{CFU} \mathrm{ml}^{-1}$ was inoculated at the rhizosphere of plants in the pots while for the double strains, and triple strains treatments, $7.5 \mathrm{ml}$ and $5.0 \mathrm{ml}$ of each bacterium media were used respectively (Gamez et al., 2019). For bacteria treatment controls (CK), we added $15 \mathrm{ml}$ of sterilized LB solution to the plant rhizosphere. The experimental design had two different controls, whereby the first group of CK consisted 
of plants with no bacterial inoculation in the soil while the second group of CK consisted of plants grown on soil with zero concentration of $\mathrm{Cd}$.

\section{Determination of chlorophyll and Cd contents}

Plant heights were measured every 7 days for 60 days. After 60 days of growth, chlorophyll contents were determined by a SPAD-502 Plus chlorophyll content analyzer (Zhejiang Top Cloud-Agri Technology Co. Ltd, China) by measuring three locations along the third flag leaf of each plant. The plants were removed from the pots and the roots washed adequately with deionized water to remove any soil adhering to the root surface. The shoots were cut from the root and fresh weights of the shoot and root were recorded. The root and shoot samples were then dried at $70^{\circ} \mathrm{C}$ in an oven for six days in order to obtain their dry weights. The samples were then ground, sieved, and $0.5 \mathrm{~g}$ of each sample digested with a mixture of $\mathrm{HCl} / \mathrm{HNO}_{3}(3: 1, \mathrm{v} / \mathrm{v})$. The concentrations of $\mathrm{Cd}$ in the digests were then determined using atomic absorption spectroscopy (AAS). To quantify $\mathrm{Cd}, 0.5 \mathrm{~g}$ of each sample was placed in a $100 \mathrm{ml}$ conical flask, $10 \mathrm{ml}$ of a 1:2 mixture of Perchloric and Nitric acid was added to each conical flask, and then left overnight. Glass funnels were placed on each flask ensuring that funnel stem did not touch the liquid in the flask. The flasks were then placed on the digestor and temperature gradually increased until the contents of the flask fully digested. The volume of the digested material was increased to $50 \mathrm{ml}$ with deionized water, then $\mathrm{Cd}$ content determined using AAS. Soils from pots of each treatment were thoroughly mixed and $\mathrm{Cd}$ content was determined in the soil samples following the digestion procedure by Sabienë et al. (2004).

\section{Quantification of the efficiency of phytoremediation}

Bioaccumulation factor (BAF) and Translocation factor (TF) were respectively determined as indicated below (González-Mendoza et al., 2007; Padmavathiamma and Li, 2007).

$$
\begin{aligned}
B A F & =\frac{\text { The metal concentration in plant tissue }(\mathrm{mg} / \mathrm{kg})}{\text { The metal concentration in soil }(\mathrm{mg} / \mathrm{kg})} \\
T F & =\frac{\text { The metal concentration in shoots }(\mathrm{mg} / \mathrm{kg})}{\text { The metal concentration in the roots }(\mathrm{mg} / \mathrm{kg})}
\end{aligned}
$$

\section{Statistical analyses}

All the data were expressed as mean with standard errors of three replicates. Twoway ANOVA (Bacteria $\mathrm{x} \mathrm{Cd}$ ) was used to determine the statistical differences across and within different treatments by using SPSS Version 20.0. Least Significant Difference (LSD) and Duncan Multiple Range Test were determined at $\mathrm{P} \leq 0.05$. Diagrams were prepared using Excel 2010.

\section{Results}

\section{Increasing levels of Cd exposure is detrimental to plant growths}

Plants grown on soils with medium to high $\mathrm{Cd}$ concentrations exhibited stunted growth with yellow leaves whereas the growth and height were better in the control. 
Plants inoculated with triple (A3A4A7) and double (A4A7) exhibited significantly higher plant heights (approx. $138 \mathrm{~cm}$ ) than all other bacteria treatments. Again, the influence of the double A3A7 and A3A4 applications were significantly better than single bacteria inoculations. Heights of plants with no bacteria inoculation $(\mathrm{CK})$ were lowest $(102.52 \mathrm{~cm})$ and differed significantly from all other treatments (Table 1). Furthermore, the results show a strong effect of the Cd stress on plant heights. Plant height significantly differed under the various $\mathrm{Cd}$ treatments with $0 \mathrm{mg} / \mathrm{kg}$ concentration the highest $(194.15 \mathrm{~cm})$ and $200 \mathrm{mg} / \mathrm{kg}$ the lowest at $85.54 \mathrm{~cm}$.

Table 1. Height of P. giganteum grown under different bacteria strains and their cocktails, and in soil amended with different concentration $\mathrm{Cd}$ ( $\mathrm{mg} / \mathrm{kg}$ soil)

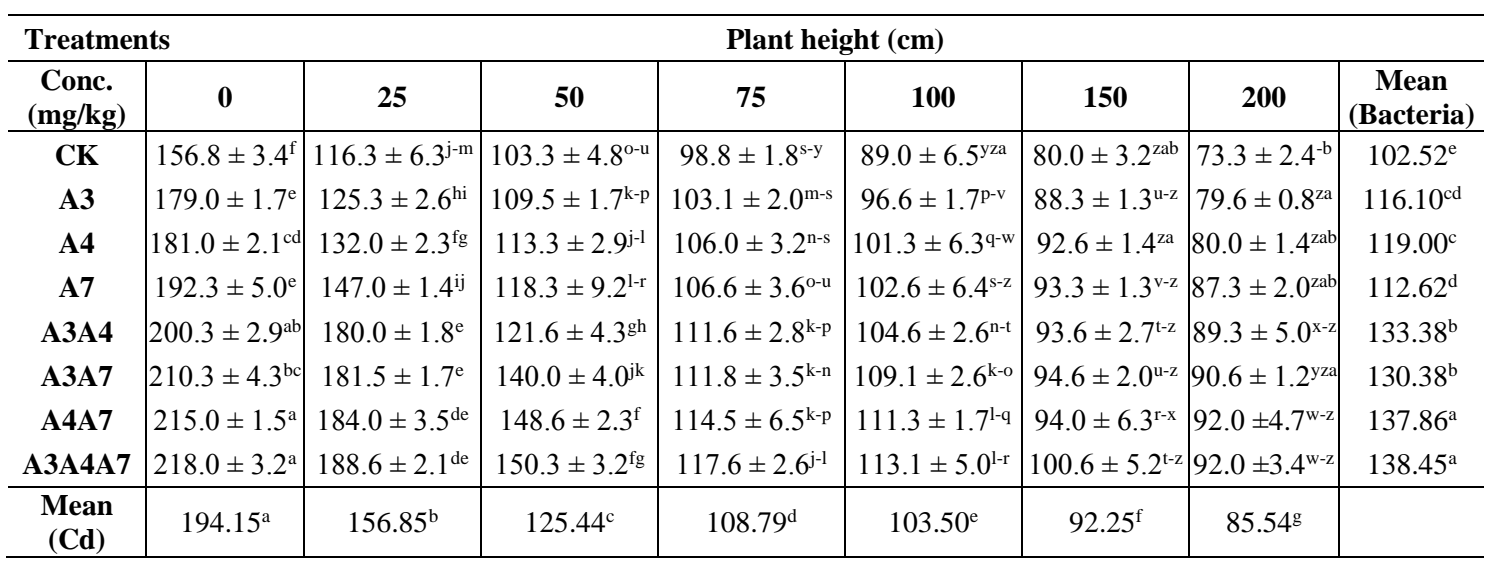

Values in each column represent the mean \pm standard error of three replicates. Those marked with different superscripts in each of the column show significant difference at $\mathrm{P} \leq 0.05$ as analyzed by LSD. The mean $\mathrm{Cd}$ analysis is within the row

The effects of the interactions of bacteria and $\mathrm{Cd}$ indicate that heights of plants inoculated with combinations of bacteria cultures were generally significantly higher than those under single strain inoculations. Height of plants with no bacteria inoculation (CK) always significantly differed from those under the influence of some bacteria showing the strong positive effect of PGPB on plant growth. Among all other applied combinations of bacteria and Cd with respect to plant height of Jujuncao, the highest was recorded at the influence of the triple A3A4A7 inoculation $(218.0 \mathrm{~cm})$ at $0 \mathrm{mg} / \mathrm{kg}$ $\mathrm{Cd}$ and the lowest at $\mathrm{CK}(73.3 \mathrm{~cm})$ at $200 \mathrm{mg} / \mathrm{kg} \mathrm{Cd}$ (Table 1).

\section{PGPB enhance growth of $P$. giganteum even in the presence $C d$}

PGPB and their cocktails significantly improve growth (plant weight and biomass) of plants grown in soils with no $\mathrm{Cd}$ compared to those with $\mathrm{Cd}$ concentrations. The triple (A3A4A7) strain application showed a significantly higher shoot fresh weight (109.25 g) than all other treatments. The influences of the double strain inoculations were generally better and significantly different from the single strain inoculations. The CK recorded the lowest weight $(48.05 \mathrm{~g})$ and was significantly different from all other treatments. Each $\mathrm{Cd}$ treatment significantly differed from the other in terms of shoot fresh weight with $0 \mathrm{mg} / \mathrm{kg} \mathrm{Cd}$ concentration recording the heaviest (128.01 g) and 200 $\mathrm{mg} / \mathrm{kg}$ recording the least weight $(60.39 \mathrm{~g})$ (Table 2$)$. 
Table 2. Shoot fresh weights of P. giganteum grown on soil amended with different concentrations of $\mathrm{Cd}(\mathrm{mg} / \mathrm{kg}$ soil) under the application of different bacteria strains and their cocktails

\begin{tabular}{|c|c|c|c|c|c|c|c|c|}
\hline \multicolumn{4}{|c|}{ Treatments } & \multicolumn{5}{|c|}{ Shoot fresh weight (g) } \\
\hline $\begin{array}{c}\text { Conc. } \\
(\mathrm{mg} / \mathrm{kg})\end{array}$ & $\mathbf{0}$ & 25 & 50 & 75 & 100 & 150 & 200 & $\begin{array}{c}\text { Mean } \\
\text { (Bacteria) }\end{array}$ \\
\hline CK & $91.1 \pm 2.1^{\mathrm{p}-\mathrm{s}}$ & $73.3 \pm 1.7^{x}$ & $51.6 \pm 1.4^{-\mathrm{a}}$ & $44.5 \pm 2.3^{-b}$ & $31.9 \pm 1.0^{-\mathrm{c}}$ & $24.6 \pm 2.3^{-\mathrm{d}}$ & $19.1 \pm 0.7^{-\mathrm{e}}$ & $48.05^{\mathrm{f}}$ \\
\hline A3 & $115.3 \pm 4.0^{3 \mathrm{f}}$ & $96.9 \pm 2.3^{1-n}$ & $82.6 \pm 2.9^{\mathrm{vw}}$ & $69.3 \pm 0.6^{x y}$ & $62.2 \pm 1.2^{\mathrm{z}}$ & $50.3 \pm 1.2^{-\mathrm{a}}$ & $40.1 \pm 1.5^{-b}$ & $73.98^{\mathrm{e}}$ \\
\hline A4 & $123.5 \pm 2.1^{\mathrm{de}}$ & $103.1 \pm 2.2^{\mathrm{h}-\mathrm{j}}$ & $84.0 \pm 1.2^{\mathrm{u}-\mathrm{w}}$ & $71.1 \pm 1.2^{\mathrm{xy}}$ & $63.3 \pm 1.3^{\mathrm{yz}}$ & $50.5 \pm 2.1^{-\mathrm{a}}$ & $43.3 \pm 1.2^{-\mathrm{b}}$ & $77.67^{\mathrm{d}}$ \\
\hline A7 & $121.0 \pm 1.7^{\mathrm{e}}$ & $99.9 \pm 1.1^{\mathrm{i}-1}$ & $86.6 \pm 1.4^{\mathrm{r}-\mathrm{v}}$ & $68.4 \pm 1.6^{x y}$ & $66.3 \pm 1.8^{\mathrm{z}}$ & $54.4 \pm 2.0^{-\mathrm{a}}$ & $42.8 \pm 1.2^{-\mathrm{b}}$ & $75.92^{\mathrm{d}}$ \\
\hline A3A4 & $140.1 \pm 0.8^{\mathrm{b}}$ & $180.0 \pm 1.8^{\mathrm{cd}}$ & $104.3 \pm 1.0^{\mathrm{hi}}$ & $98.5 \pm 1.4^{j-\mathrm{n}}$ & $94.6 \pm 3.4^{\mathrm{m}-\mathrm{p}}$ & $87.9 \pm 1.5^{\mathrm{r}-\mathrm{u}}$ & $85.1 \pm 3.6^{\mathrm{t}-\mathrm{w}}$ & $105.57^{\mathrm{bc}}$ \\
\hline A3A7 & $142.3 \pm 0.8^{\mathrm{ab}}$ & $128.3 \pm 1.3^{\mathrm{c}}$ & $102.4 \pm 2.0^{\mathrm{h}-\mathrm{k}}$ & $95.5 \pm 0.4^{1-\mathrm{p}}$ & $93.7 \pm 0.9^{\mathrm{n}-\mathrm{q}}$ & $88.5 \pm 1.1^{\mathrm{r}-\mathrm{u}}$ & $81.5 \pm 1.1^{\mathrm{w}}$ & $104.76^{c}$ \\
\hline A4A7 & $144.0 \pm 0.6^{\mathrm{ab}}$ & $129.8 \pm 1.1^{\mathrm{c}}$ & $106.9 \pm 1.3^{\mathrm{gh}}$ & $99.5 \pm 0.9^{i-m}$ & $96.4 \pm 1.4^{1-\mathrm{o}}$ & $89.2 \pm 0.6^{\mathrm{q}-\mathrm{t}}$ & $84.8 \pm 2.3^{t-w}$ & $107.25^{\mathrm{b}}$ \\
\hline A3A4A7 & $146.7 \pm 1.2^{\mathrm{a}}$ & $127.7 \pm 1.6^{\mathrm{cd}}$ & $111.8 \pm 2.1^{\mathrm{fg}}$ & $103.2 \pm 0.8^{\mathrm{h}-\mathrm{j}}$ & $97.5 \pm 1.2^{\mathrm{k}-\mathrm{n}}$ & $91.4 \pm 1.2^{\mathrm{o}-\mathrm{r}}$ & $86.4 \pm 1.3^{s-w}$ & $109.25^{\mathrm{a}}$ \\
\hline $\begin{array}{c}\text { Mean } \\
(\mathrm{Cd})\end{array}$ & $128.01^{\mathrm{a}}$ & $111.08^{\mathrm{b}}$ & $91.30^{c}$ & $81.25^{\mathrm{d}}$ & $75.74^{e}$ & $66.87^{\mathrm{f}}$ & $60.39^{\mathrm{g}}$ & \\
\hline
\end{tabular}

Values in each column represent the mean \pm standard error of three replicates. Those marked with different superscripts in each of the column show significant difference at $\mathrm{P} \leq 0.05$ as analyzed by LSD. The mean $\mathrm{Cd}$ analysis is within the row

The best influence of the strains on root fresh weights were recorded at the double inoculations A4A7 (12.73 g), A3A4 (12.46 g) and A3A7 (12.44 g) which were significantly better than all other treatments. Generally, the single strain inoculations significantly differed from the cocktail inoculations. The CK recorded the lowest weight and differed significantly from all others. The effects of the Cd treatments on root fresh weights were significantly different from each other (Table 3).

Table 3. Root fresh weights of P. giganteum grown on soil amended with different concentrations of $\mathrm{Cd}(\mathrm{mg} / \mathrm{kg}$ soil) under the application of different bacteria strains and their cocktails

\begin{tabular}{|c|c|c|c|c|c|c|c|c|}
\hline \multicolumn{4}{|c|}{ Treatments } & \multicolumn{5}{|c|}{ Root fresh weight (g) } \\
\hline $\begin{array}{c}\text { Conc. } \\
\text { (mg/kg) }\end{array}$ & $\mathbf{0}$ & 25 & 50 & 75 & 100 & 150 & 200 & $\begin{array}{c}\text { Mean } \\
\text { (Bacteria) }\end{array}$ \\
\hline CK & $13.5 \pm 1.0^{\mathrm{f}-\mathrm{i}}$ & $9.4 \pm 0.5^{\mathrm{q}-\mathrm{t}}$ & $8.4 \pm 0.3^{\mathrm{u}-\mathrm{z}}$ & $7.0 \pm 0.1^{-\mathrm{b}-\mathrm{f}}$ & $6.8 \pm 0.4^{-\mathrm{b}-\mathrm{f}}$ & $6.1 \pm 0.2^{-\mathrm{fg}}$ & $5.6 \pm 0.5^{-\mathrm{g}}$ & $8.13^{\mathrm{e}}$ \\
\hline $\mathbf{A 3}$ & $14.4 \pm 0.5^{\mathrm{ef}}$ & $13.0 \pm 0.1^{\mathrm{h}-\mathrm{j}}$ & $12.0 \pm 0.3^{\mathrm{k}-\mathrm{m}}$ & $10.0 \pm 0.5^{\mathrm{p}-\mathrm{s}}$ & $8.7 \pm 0.2^{\mathrm{t}-\mathrm{y}}$ & $7.3 \pm 0.4^{-\mathrm{a}-\mathrm{d}}$ & $6.4 \pm 0.1^{-\mathrm{d}-\mathrm{g}}$ & $10.26^{\mathrm{d}}$ \\
\hline A4 & $14.5 \pm 0.4^{\mathrm{e}}$ & $13.8 \pm 0.2^{\mathrm{e}-\mathrm{h}}$ & $12.5 \pm 0.3^{\mathrm{i}-\mathrm{k}}$ & $10.4 \pm 0.3^{o-q}$ & $9.6 \pm 0.3^{q-t}$ & $7.5 \pm 0.3^{z-c}$ & $6.6 \pm 0.2^{-\mathrm{c}-\mathrm{f}}$ & $10.71^{\mathrm{c}}$ \\
\hline A7 & $14.2 \pm 0.6^{\mathrm{e}-\mathrm{g}}$ & $13.3 \pm 0.3^{\mathrm{g}-\mathrm{i}}$ & $11.9 \pm 0.1^{\mathrm{k}-\mathrm{n}}$ & $10.1 \pm 0.2^{\mathrm{p}-\mathrm{r}}$ & $8.7 \pm 0.1^{\mathrm{t}-\mathrm{x}}$ & $7.1 \pm 0.1^{-\mathrm{a}-\mathrm{e}}$ & $6.3 \pm 0.1^{-\mathrm{e}-\mathrm{g}}$ & $10.22^{\mathrm{d}}$ \\
\hline A3A4 & $17.3 \pm 0.6^{\mathrm{a}-\mathrm{c}}$ & $17.2 \pm 0.4^{\mathrm{a}-\mathrm{c}}$ & $13.1 \pm 0.5^{\mathrm{h}-\mathrm{j}}$ & $11.8 \pm 0.2^{\mathrm{k}-\mathrm{m}}$ & $10.9 \pm 0.4^{\mathrm{n}-\mathrm{p}}$ & $9.1 \pm 0.3^{\mathrm{r}-\mathrm{v}}$ & $7.7 \pm 0.5^{\mathrm{y}-\mathrm{b}}$ & $12.46^{\mathrm{ab}}$ \\
\hline A3A7 & $17.0 \pm 0.3^{\mathrm{a}-\mathrm{c}}$ & $16.5 \pm 0.5^{\mathrm{cd}}$ & $13.1 \pm 0.4^{\mathrm{h}-\mathrm{j}}$ & $12.2 \pm 0.3^{\mathrm{j}-1}$ & $11.2 \pm 0.3^{\mathrm{m}-\mathrm{o}}$ & $9.0 \pm 0.1^{\mathrm{s}-\mathrm{w}}$ & $8.0 \pm 0.3^{\mathrm{x}-\mathrm{a}}$ & $12.44^{\mathrm{ab}}$ \\
\hline A4A7 & $17.8 \pm 1.1^{\mathrm{a}}$ & $16.6 \pm 0.4^{\mathrm{b}-\mathrm{d}}$ & $13.3 \pm 0.4^{\mathrm{g}-\mathrm{i}}$ & $12.2 \pm 0.2^{\mathrm{j}-\mathrm{m}}$ & $11.5 \pm 0.2^{1-\mathrm{n}}$ & $9.4 \pm 0.2^{\mathrm{q}-\mathrm{u}}$ & $8.4 \pm 0.3^{\mathrm{v}-\mathrm{z}}$ & $12.73^{\mathrm{a}}$ \\
\hline A3A4A7 & $17.5 \pm 0.7^{\mathrm{ab}}$ & $15.9 \pm 0.4^{\mathrm{d}}$ & $13.7 \pm 0.3^{\mathrm{e}-\mathrm{h}}$ & $11.6 \pm 0.2^{\mathrm{k}-\mathrm{m}}$ & $10.4 \pm 0.1^{\mathrm{o}-\mathrm{q}}$ & $9.2 \pm 0.3^{\mathrm{r}-\mathrm{v}}$ & $8.0 \pm 0.2^{\mathrm{w}-\mathrm{a}}$ & $12.31^{\mathrm{b}}$ \\
\hline $\begin{array}{c}\text { Mean } \\
(\text { Cd })\end{array}$ & $15.74^{\mathrm{a}}$ & $14.46^{\mathrm{b}}$ & $12.25^{\mathrm{c}}$ & $10.67^{\mathrm{d}}$ & $9.74^{\mathrm{e}}$ & $8.10^{\mathrm{f}}$ & $7.16^{\mathrm{g}}$ & \\
\hline
\end{tabular}

The values in each column represent the mean \pm standard error of three replicates. Those marked with different superscripts in each of the column show significant difference at $\mathrm{P} \leq 0.05$ as analyzed by LSD. The mean Cd analysis is within the row

The effects of the bacteria on shoot dry weights indicated that combinations A3A4A7 and A4A7 showed significantly higher weights (approx. $36 \mathrm{~g}$ ) than all other bacterial treatments. Here too, the single strain inoculations significantly differed from 
the cocktail inoculations. The CK recorded the least weight (18.70 g) and significantly differed from all other recordings. The effects of the $\mathrm{Cd}$ stress were significantly different from each other (Table 4). These observations were generally similar for the root dry weights as presented in Table 5.

Table 4. Shoot dry weights of $P$. giganteum grown on soil amended with different concentrations of $C d(\mathrm{mg} / \mathrm{kg}$ soil) under the application of different bacteria strains and their cocktails

\begin{tabular}{|c|c|c|c|c|c|c|c|c|}
\hline \multicolumn{4}{|c|}{ Treatments } & \multicolumn{5}{|c|}{ Shoot dry weight (g) } \\
\hline $\begin{array}{c}\text { Conc. } \\
(\mathrm{mg} / \mathrm{kg})\end{array}$ & $\mathbf{0}$ & 25 & 50 & 75 & 100 & 150 & 200 & \begin{tabular}{|c|} 
Mean \\
(Bacteria)
\end{tabular} \\
\hline CK & $32.3 \pm 0.8^{\mathrm{mn}}$ & $21.5 \pm 0.4^{-\mathrm{b}}$ & $19.0 \pm 0.2^{-\mathrm{c}}$ & $16.6 \pm 0.4^{-\mathrm{d}}$ & $6.8 \pm 0.4^{-\mathrm{d}}$ & $13.5 \pm 0.2^{-\mathrm{e}}$ & $12.3 \pm 0.3^{-\mathrm{e}}$ & $18.70^{\mathrm{f}}$ \\
\hline $\mathbf{A 3}$ & $40.1 \pm 1.3^{\mathrm{g}}$ & $34.2 \pm 0.8^{1}$ & $30.1 \pm 0.9^{\mathrm{o}-\mathrm{q}}$ & $27.4 \pm 0.7^{s-u}$ & $8.7 \pm 0.2^{\mathrm{u}-\mathrm{w}}$ & $24.6 \pm 0.2^{x-z}$ & $23.7 \pm 0.3^{\mathrm{ya}}$ & $29.48^{e}$ \\
\hline A4 & $43.8 \pm 0.7^{\mathrm{cd}}$ & $39.3 \pm 0.4^{\mathrm{gh}}$ & $34.0 \pm 0.6^{1}$ & $28.8 \pm 0.2^{\mathrm{q}-\mathrm{s}}$ & $9.6 \pm 0.3^{\mathrm{v-x}}$ & $23.2 \pm 0.2^{\mathrm{za}}$ & $24.7 \pm 0.3^{\mathrm{w}-\mathrm{z}}$ & $31.33^{c}$ \\
\hline A7 & $40.6 \pm 0.6^{\mathrm{fg}}$ & $39.5 \pm 1.2^{\mathrm{gh}}$ & $33.7 \pm 0.61^{\mathrm{m}}$ & $27.4 \pm 0.6^{s-u}$ & $8.7 \pm 0.3^{\mathrm{v}-\mathrm{x}}$ & $24.9 \pm 0.2^{\mathrm{w}-\mathrm{y}}$ & $23.0 \pm 0.5^{-\mathrm{ab}}$ & $30.69^{d}$ \\
\hline A3A4 & $46.6 \pm 0.7^{\mathrm{b}}$ & $42.5 \pm 0.8^{\text {de }}$ & $37.1 \pm 0.6^{\mathrm{ij}}$ & $33.6 \pm 0.3^{\operatorname{lm}}$ & $10.9 \pm 0.4^{\mathrm{no}}$ & $28.7 \pm 0.4^{\mathrm{q}-\mathrm{s}}$ & $27.8 \pm 0.3^{\mathrm{r}-\mathrm{u}}$ & $35.41^{\mathrm{b}}$ \\
\hline A3A7 & $46.9 \pm 0.7^{\mathrm{ab}}$ & $42.2 \pm 0.9^{\mathrm{ef}}$ & $36.5 \pm 0.3^{\mathrm{jk}}$ & $33.8 \pm 0.9^{\mathrm{Im}}$ & $11.2 \pm 0.3^{\mathrm{n}-\mathrm{p}}$ & $27.9 \pm 0.3^{\mathrm{r}-\mathrm{t}}$ & $26.6 \pm 0.3^{\mathrm{t}-\mathrm{v}}$ & $35.00^{\mathrm{b}}$ \\
\hline A4A7 & $48.0 \pm 0.3^{\mathrm{ab}}$ & $44.4 \pm 0.5^{\mathrm{c}}$ & $37.3 \pm 0.6^{\mathrm{ij}}$ & $34.5 \pm 0.5^{1}$ & $11.5 \pm 0.2^{\mathrm{n}-\mathrm{p}}$ & $29.0 \pm 0.2^{\text {qr }}$ & $27.8 \pm 0.3^{\mathrm{r}-\mathrm{u}}$ & $36.02^{\mathrm{a}}$ \\
\hline A3A4A7 & $48.3 \pm 0.6^{\mathrm{a}}$ & $44.4 \pm 0.6^{\mathrm{c}}$ & $38.5 \pm 0.5^{\mathrm{hi}}$ & $35.1 \pm 0.3^{\mathrm{kl}}$ & $10.4 \pm 0.1^{\mathrm{no}}$ & $29.7 \pm 0.3^{\mathrm{pq}}$ & $27.9 \pm 0.5^{\mathrm{r}-\mathrm{t}}$ & $36.46^{\mathrm{a}}$ \\
\hline $\begin{array}{c}\text { Mean } \\
(\mathrm{Cd})\end{array}$ & $43.34^{\mathrm{a}}$ & $38.49^{\mathrm{b}}$ & $33.29^{c}$ & $29.66^{\mathrm{d}}$ & $27.23^{\mathrm{e}}$ & $25.21^{\mathrm{f}}$ & $24.23^{\mathrm{g}}$ & \\
\hline
\end{tabular}

The values in each column represent the mean \pm standard error of three replicates. Those marked with different superscripts in each of the column show significant difference at $\mathrm{P} \leq 0.05$ as analyzed by LSD.

The mean $\mathrm{Cd}$ analysis is within the row

Table 5. Root dry weights of $P$. giganteum grown on soil amended with different concentrations of $\mathrm{Cd}(\mathrm{mg} / \mathrm{kg}$ soil) under the application of different bacteria strains and their cocktails

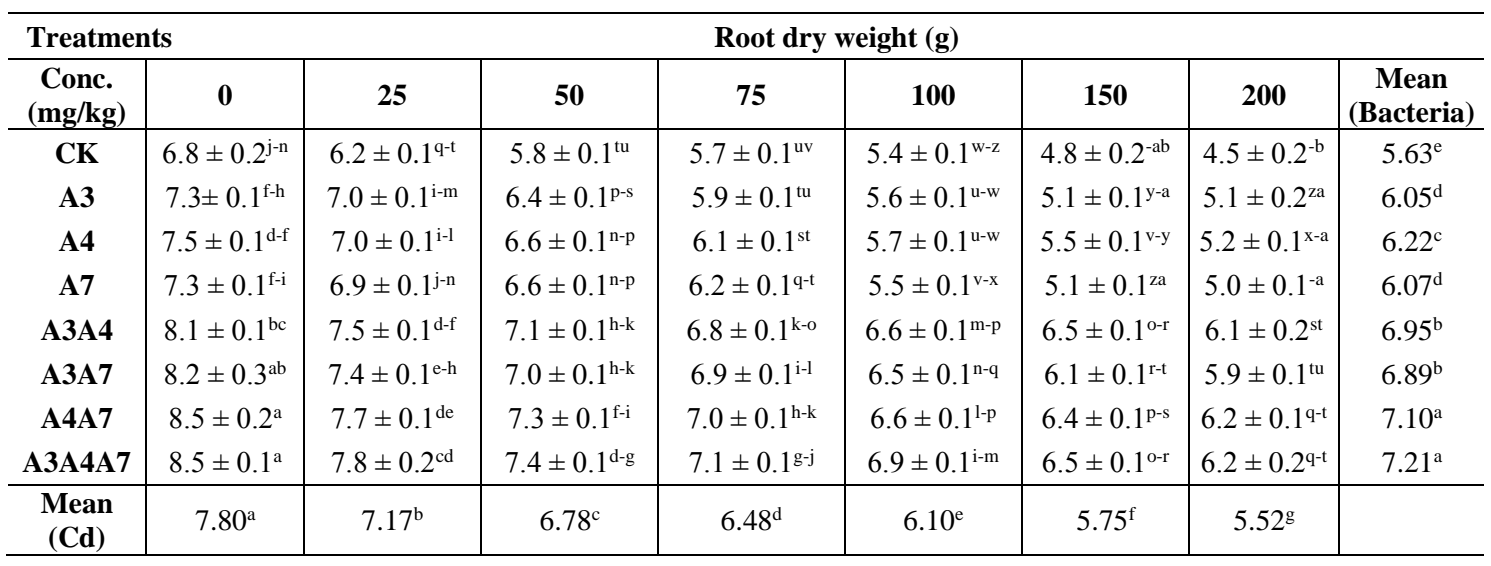

Values in each column represent the mean \pm standard error of three replicates. Those marked with different superscripts in each of the column show significant difference at $\mathrm{P} \leq 0.05$ as analyzed by LSD. The mean Cd analysis is within the row

The interaction effects of bacteria and Cd on weights of shoots and roots of Jujuncao generally indicate that combinations of bacteria culture recorded significantly higher values than single strains inoculations which were also always significantly higher than the $\mathrm{CK}$ at the various $\mathrm{Cd}$ stress levels. As concentrations of metals increased from $25 \mathrm{mg} / \mathrm{kg}$ onwards to $200 \mathrm{mg} / \mathrm{kg}$, the influence of the bacteria on growths reduced 
progressively suggesting that a threshold exists beyond which the bacteria may not alleviate toxicity of the metals in plants. Similarly, as $\mathrm{Cd}$ concentration increased towards $200 \mathrm{mg} / \mathrm{kg}$, the effect of the various bacteria treatments on plant growth dramatically decreased. The negative effect of the metal on plants grown in pots without PGPB was so severe that the yellowing of leaves and drying of leaf tips were profound at $200 \mathrm{mg} / \mathrm{kg} \mathrm{Cd}$ concentration.

\section{Plants inoculated with PGPB accumulated more Cd in their tissues}

Cadmium concentrations in the different plant parts grown in the contaminated soil are presented in Tables 6 and 7. The effects of the PGPB on shoot $\mathrm{Cd}$ indicate that there was no significant difference between either the triple or double consortia applications. However, significant difference exists between cocktail of strains inoculation and single inoculation. The $\mathrm{CK}$ recorded the lowest shoot $\mathrm{Cd}$ of $28.18 \mathrm{mg} / \mathrm{kg}$ which was significantly different from all the bacteria treatments. Cd accumulation in shoots had an interesting pattern; for all $\mathrm{Cd}$ treatments, the $\mathrm{Cd}$ contents progressively increased up to $50 \mathrm{mg} / \mathrm{kg} \mathrm{Cd}$, after which it had an inverse relation with the Cd concentrations in the soil. The maximum cadmium uptake in shoot, $55.1 \mathrm{mg} / \mathrm{kg}$, was recorded in plants inoculated with A3A4A7 at $50 \mathrm{mg} / \mathrm{kg}$ Cd concentration. The quantities of $\mathrm{Cd}$ in the shoot of plants treated with 0 to $50 \mathrm{mg} / \mathrm{kg} \mathrm{Cd}$ was in the range of 0.01 to $55.1 \mathrm{mg} / \mathrm{kg}$ whereas treatments of 75 to $200 \mathrm{mg} / \mathrm{kg} \mathrm{Cd}$ were in the range of $25.3 \mathrm{mg} / \mathrm{kg}$ (at 200 $\mathrm{mg} / \mathrm{kg} \mathrm{Cd}$ with no bacteria) to $46.0 \mathrm{mg} / \mathrm{kg}$ (at $75 \mathrm{mg} / \mathrm{kg} \mathrm{Cd}$ with A3A4A7 bacteria inoculation). The pattern for shoot $\mathrm{Cd}$ content in terms of the PGPB influence was: cocktails $>$ single $>$ no bacteria (Table 6$)$.

Table 6. Concentrations of $C d$ in shoots of $P$. giganteum grown in different concentrations of Cd contaminated soil, under the application of different bacteria strains and their cocktails

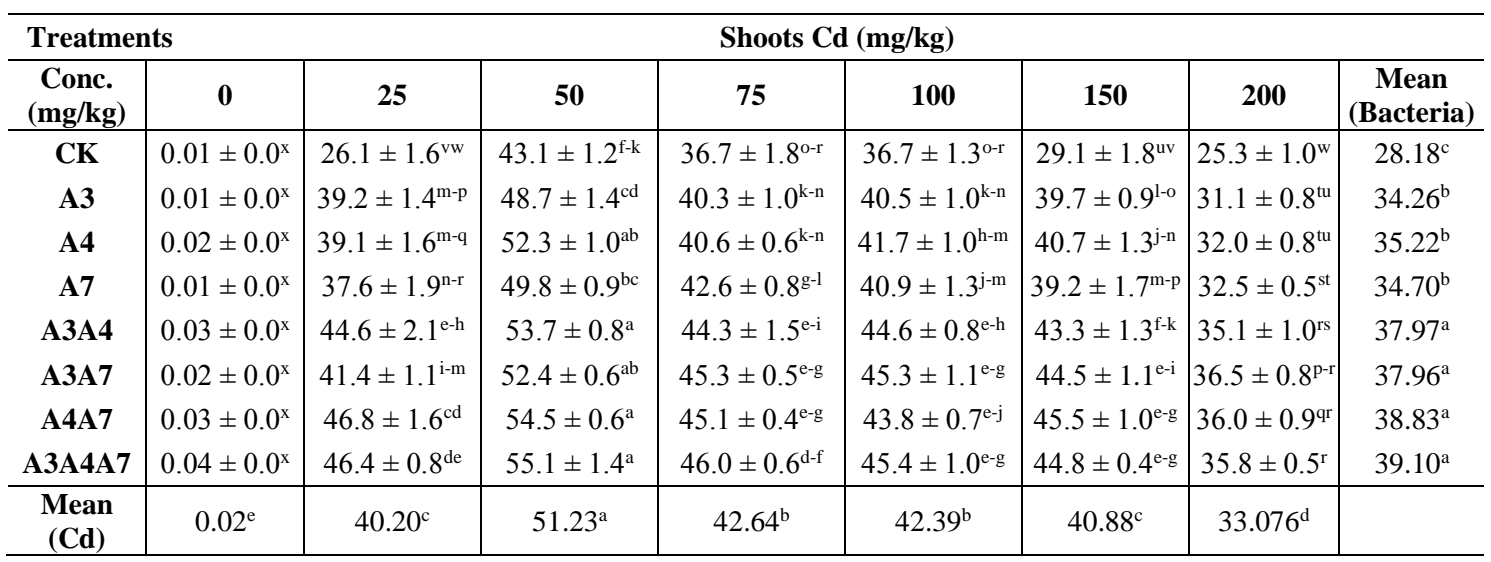

Values in each column represent the mean \pm standard error of three replicates. Those marked with different superscripts in each of the column show significant difference at $\mathrm{P} \leq 0.05$ as analyzed by LSD. The mean $\mathrm{Cd}$ analysis is within the row

The effects of the bacteria strains on root Cd uptake showed that the inoculation of triple A3A4A7 and double A4A7 were significantly higher than all other bacterial treatments. The effects of the single strain inoculations were lower and significantly different from the combination treatments. A CK value of 42.07 was significantly lower than all other bacterial treatments. Generally, the pattern of the root Cd content in terms of the bacterial application was as follows: cocktails $>$ single $>$ no bacteria. On the other 
hand, the highest mean root Cd value of $78.83 \mathrm{mg} / \mathrm{kg}$ was obtained at $200 \mathrm{mg} / \mathrm{kg}$ whereas the lowest mean root Cd value of $0.045 \mathrm{mg} / \mathrm{kg}$ was recorded at $0 \mathrm{mg} / \mathrm{kg}$ Cd concentration. Maximum cadmium uptake in root of $83.5 \mathrm{mg} / \mathrm{kg}$ was recorded at the interaction of $200 \mathrm{mg} / \mathrm{kg} \mathrm{Cd}$ and the consortium of the triple bacteria inoculation (Table 7).

Table 7. Concentrations of $C d$ in roots of $P$. giganteum grown in different concentrations of $C d$ contaminated soil, under the application of different bacteria strains and their cocktails

\begin{tabular}{c|c|c|c|c|c|c|c|c}
\hline \multicolumn{1}{l}{ Treatments } \\
$\begin{array}{c}\text { Conc. } \\
\text { (mg/kg) }\end{array}$ & $\mathbf{0}$ & $\mathbf{2 5}$ & $\mathbf{5 0}$ & $\mathbf{7 5}$ & $\mathbf{1 0 0}$ & $\mathbf{1 5 0}$ & $\mathbf{2 0 0}$ & $\begin{array}{c}\text { Mean } \\
(\text { Bacteria) }\end{array}$ \\
\hline $\mathbf{C K}$ & $0.02 \pm 0.0^{\mathrm{a}}$ & $30.0 \pm 1.1^{\mathrm{z}}$ & $48.5 \pm 0.8^{\mathrm{u}}$ & $48.6 \pm 1.3^{\mathrm{u}}$ & $50.1 \pm 1.4^{\mathrm{st}}$ & $55.3 \pm 0.8^{\mathrm{u}}$ & $61.8 \pm 0.7^{\mathrm{k}-\mathrm{n}}$ & $42.07^{\mathrm{e}}$ \\
$\mathbf{A 3}$ & $0.02 \pm 0.0^{\mathrm{a}}$ & $37.6 \pm 0.9^{\mathrm{y}}$ & $49.7 \pm 3.4^{\mathrm{u}}$ & $56.1 \pm 1.4^{\mathrm{q}-\mathrm{t}}$ & $69.9 \pm 1.3^{\mathrm{g}}$ & $69.7 \pm 2.6^{\mathrm{h}}$ & $78.8 \pm 0.7^{\mathrm{c}-\mathrm{e}}$ & $51.16^{\mathrm{d}}$ \\
$\mathbf{A 4}$ & $0.04 \pm 0.0^{\mathrm{a}}$ & $38.9 \pm 0.4^{\mathrm{xy}}$ & $55.4 \pm 0.9^{\mathrm{r}-\mathrm{t}}$ & $58.4 \pm 0.9^{\mathrm{o}-\mathrm{q}}$ & $62.5 \pm 1.1^{\mathrm{fg}}$ & $72.2 \pm 0.9^{\mathrm{j}-\mathrm{m}}$ & $81.0 \pm 1.0^{\mathrm{a}-\mathrm{c}}$ & $52.64^{\mathrm{c}}$ \\
$\mathbf{A 7}$ & $0.03 \pm 0.0^{\mathrm{a}}$ & $36.5 \pm 0.7^{\mathrm{y}}$ & $54.2 \pm 0.5^{\mathrm{t}}$ & $57.2 \pm 1.2^{\mathrm{p}-\mathrm{s}}$ & $65.1 \pm 0.4^{\mathrm{hi}}$ & $65.2 \pm 0.5^{\mathrm{h}-\mathrm{j}}$ & $80.6 \pm 1.6^{\mathrm{b}-\mathrm{d}}$ & $51.28^{\mathrm{d}}$ \\
$\mathbf{A 3 A 4}$ & $0.06 \pm 0.0^{\mathrm{a}}$ & $41.7 \pm 0.9^{\mathrm{w}}$ & $59.4 \pm 0.6^{\mathrm{n}-\mathrm{p}}$ & $63.0 \pm 0.2^{\mathrm{i}-\mathrm{l}}$ & $71.4 \pm 0.2^{\mathrm{f}}$ & $73.8 \pm 0.6^{\mathrm{fg}}$ & $80.6 \pm 0.6^{\mathrm{b}-\mathrm{d}}$ & $55.72^{\mathrm{b}}$ \\
$\mathbf{A 3 A 7}$ & $0.05 \pm 0.0^{\mathrm{a}}$ & $41.2 \pm 1.2^{\mathrm{wx}}$ & $58.1 \pm 1.1^{\mathrm{o}-\mathrm{r}}$ & $61.9 \pm 0.2^{\mathrm{k}-\mathrm{n}}$ & $73.0 \pm 0.1^{\mathrm{e}}$ & $77.1 \pm 0.1^{\mathrm{f}}$ & $81.0 \pm 0.2^{\mathrm{a}-\mathrm{c}}$ & $56.07^{\mathrm{b}}$ \\
$\mathbf{A 4 A 7}$ & $0.06 \pm 0.0^{\mathrm{a}}$ & $44.4 \pm 1.1^{\mathrm{v}}$ & $60.4 \pm 0.6^{\mathrm{l}-\mathrm{o}}$ & $64.2 \pm 0.3^{\mathrm{h}-\mathrm{k}}$ & $70.1 \pm 0.3^{\mathrm{de}}$ & $77.9 \pm 0.4^{\mathrm{g}}$ & $83.1 \pm 0.5^{\mathrm{ab}}$ & $57.21^{\mathrm{a}}$ \\
$\mathbf{A 3 A 4 A 7}$ & $0.07 \pm 0.0^{\mathrm{a}}$ & $45.5 \pm 0.1^{\mathrm{v}}$ & $60.0 \pm 0.3^{\mathrm{m}-\mathrm{o}}$ & $64.8 \pm 0.1^{\mathrm{h}-\mathrm{j}}$ & $73.1 \pm 0.3^{\mathrm{de}}$ & $78.1 \pm 0.1^{\mathrm{f}}$ & $83.5 \pm 0.2^{\mathrm{a}}$ & $57.89^{\mathrm{a}}$ \\
\hline $\begin{array}{c}\text { Mean } \\
(\mathbf{C d})\end{array}$ & $0.045^{\mathrm{g}}$ & $39.504^{\mathrm{f}}$ & $55.746^{\mathrm{e}}$ & $59.313^{\mathrm{d}}$ & $71.196^{\mathrm{b}}$ & $66.412^{\mathrm{c}}$ & $78.83^{\mathrm{a}}$ & \\
\hline
\end{tabular}

Values in each column represent the mean \pm standard error of three replicates. Those marked with different superscripts in each of the column show significant difference at $\mathrm{P} \leq 0.05$ as analyzed by LSD. The mean $\mathrm{Cd}$ analysis is within the row

\section{$P$. giganteum chlorophyll content responses against $C$-induced oxidative stress in different bacteria inoculation}

The chlorophyll content of plants under triple strain inoculation was significantly higher (32.52) than all other bacterial treatments. There was no significant difference in the chlorophyll contents of the double strain inoculated plants which were however significantly higher than the single strain inoculated plants. The CK showed a significantly least value of 23.21. On the other hand, the chlorophyll contents of the plants had an inverse relationship with the concentration of $\mathrm{Cd}$ with the highest chlorophyll content of 46.76 being recorded at $0 \mathrm{mg} / \mathrm{kg}$ Cd concentration and the lowest value of 16.63 recorded at $200 \mathrm{mg} / \mathrm{kg} \mathrm{Cd}$ concentration. The chlorophyll content significantly differed from each other at the various $\mathrm{Cd}$ concentrations. The interactions of the bacteria strains and the $\mathrm{Cd}$ revealed the maximum mean chlorophyll content was 55.1 recorded in plants inoculated with $\mathrm{A} 3 \mathrm{~A} 4 \mathrm{~A} 7$ strains at $0 \mathrm{Cd}$ concentration, whereas the minimum chlorophyll content of 15.2 was recorded from plants at $200 \mathrm{mg} / \mathrm{kg} \mathrm{Cd}$ supplied with no bacteria application (Table 8).

\section{Effect of cadmium on bioaccumulation and translocation factors}

Bioaccumulation factor (BAF) and Translocation factor (TF) are widely used to determine the uptake and translocations of heavy metals into growing plant tissues. BAF is used to measure the efficiency of plant species in accumulating heavy metals from soil environment into its tissues. On the other hand, TF is a measurement of the efficiency of a plant's ability to translocate metals accumulated from its roots to its shoots (Ladislas et al., 2012). 
The BAF for shoot at $25 \mathrm{mg} / \mathrm{kg} \mathrm{Cd}$ were all above 1.0, whereas the BAF values for shoot at $50 \mathrm{mg} / \mathrm{kg}$ were all above 1.0 with the exceptions of the $\mathrm{CK}$ and $\mathrm{A} 3$ inoculations. Above $50 \mathrm{mg} / \mathrm{kg}$ Cd treatments, the BAF values progressively decreased below 1.0 as $\mathrm{Cd}$ concentration increased. Overall, shoot $\mathrm{BAF}$ values were in the range of $0.13(\mathrm{CK}, 200 \mathrm{mg} / \mathrm{kg}$ ) to 1.87 (A4A7, $25 \mathrm{mg} / \mathrm{kg}$ ) (Figure 1a).

Table 8. Chlorophyll content response of $P$. giganteum plants under different concentrations of $\mathrm{Cd}(\mathrm{mg} / \mathrm{kg}$ soil) under the application of different bacteria strains and their cocktails

\begin{tabular}{|c|c|c|c|c|c|c|c|c|}
\hline \multicolumn{9}{|c|}{ Treatments } \\
\hline $\begin{array}{c}\text { Conc. } \\
\text { (mg/kg) }\end{array}$ & $\mathbf{0}$ & 25 & 50 & 75 & 100 & 150 & 200 & $\begin{array}{c}\text { Mean } \\
\text { (Bacteria) }\end{array}$ \\
\hline CK & $35.6 \pm 0.99^{\mathrm{g}}$ & $30.1 \pm 1.71^{\mathrm{hi}}$ & $23.3 \pm 0.69^{\mathrm{n}-\mathrm{q}}$ & $21.7 \pm 0.47^{p-s}$ & $19.8 \pm 0.78^{\mathrm{r}-\mathrm{u}}$ & $16.4 \pm 0.84^{\mathrm{wx}}$ & $15.2 \pm 0.58^{x}$ & $23.21^{\mathrm{e}}$ \\
\hline A3 & $41.8 \pm 1.48^{f}$ & $36.3 \pm 1.14^{\mathrm{g}}$ & $26.7 \pm 0.91^{\mathrm{kl}}$ & $23.6 \pm 1.05^{\mathrm{m}-\mathrm{p}}$ & $22.3 \pm 0.66^{\mathrm{o}-\mathrm{r}}$ & $19.3 \pm 0.81^{\mathrm{s}-\mathrm{v}}$ & $16.1 \pm 0.40^{\mathrm{wx}}$ & $26.60^{\mathrm{d}}$ \\
\hline A4 & $42.4 \pm 1.24^{\mathrm{f}}$ & $40.0 \pm 1.79^{\mathrm{f}}$ & $26.8 \pm 0.52^{\mathrm{kl}}$ & $24.4 \pm 0.73^{1-0}$ & $23.1 \pm 0.35^{\mathrm{o}-\mathrm{q}}$ & $20.3 \pm 0.47^{\mathrm{r}-\mathrm{t}}$ & $16.5 \pm 0.44^{w x}$ & $27.69^{c}$ \\
\hline A7 & $41.2 \pm 1.53^{\mathrm{f}}$ & $35.4 \pm 1.10^{\mathrm{g}}$ & $25.9 \pm 0.41^{\mathrm{k}-\mathrm{m}}$ & $23.2 \pm 0.49^{\mathrm{n}-\mathrm{q}}$ & $22.0 \pm 0.29^{\mathrm{o}-\mathrm{r}}$ & $18.4 \pm 0.21^{\mathrm{t}-\mathrm{w}}$ & $16.5 \pm 0.69^{w x}$ & $26.12^{\mathrm{d}}$ \\
\hline A3A4 & $52.5 \pm 1.24^{\mathrm{bc}}$ & $47.4 \pm 1.04^{\mathrm{e}}$ & $30.2 \pm 0.79^{\mathrm{hi}}$ & $25.9 \pm 0.44^{\mathrm{k}-\mathrm{m}}$ & $24.4 \pm 0.23^{1-\mathrm{O}}$ & $22.0 \pm 0.95^{\mathrm{o}-\mathrm{r}}$ & $17.0 \pm 0.27^{v-x}$ & $30.99^{b}$ \\
\hline A3A7 & $51.3 \pm 1.18^{\mathrm{c}}$ & $48.4 \pm 1.19^{\mathrm{de}}$ & $29.3 \pm 0.64^{\mathrm{h}-\mathrm{j}}$ & $25.7 \pm 0.27^{\mathrm{k}-\mathrm{n}}$ & $23.5 \pm 0.55^{\mathrm{m}-\mathrm{p}}$ & $21.3 \pm 0.67^{\mathrm{p}-\mathrm{s}}$ & $17.1 \pm 0.19^{v-x}$ & $31.40^{\mathrm{b}}$ \\
\hline A4A7 & $54.0 \pm 0.78^{\mathrm{ab}}$ & $47.5 \pm 1.15^{\mathrm{e}}$ & $29.8 \pm 1.32^{\mathrm{h}-\mathrm{j}}$ & $27.4 \pm 1.19^{\mathrm{jk}}$ & $23.0 \pm 0.67^{0-q}$ & $21.0 \pm 0.58^{q-s}$ & $17.0 \pm 0.58^{v-x}$ & $31.43^{\mathrm{b}}$ \\
\hline A3A4A7 & $55.1 \pm 1.15^{\mathrm{a}}$ & $50.6 \pm 0.99^{\mathrm{cd}}$ & $30.8 \pm 1.45^{\mathrm{h}}$ & $28.1 \pm 0.82^{\mathrm{i}-\mathrm{k}}$ & $23.7 \pm 0.59^{\mathrm{m}-\mathrm{p}}$ & $21.9 \pm 0.74^{\mathrm{p}-\mathrm{r}}$ & $17.4 \pm 0.35^{\mathrm{u}-\mathrm{x}}$ & $32.52^{\mathrm{a}}$ \\
\hline $\begin{array}{c}\text { Mean } \\
(\text { Cd })\end{array}$ & $46.76^{\mathrm{a}}$ & $41.98^{\mathrm{b}}$ & $27.90^{c}$ & $25.04^{\mathrm{d}}$ & $22.77^{\mathrm{e}}$ & $20.13^{\mathrm{f}}$ & $16.63^{\mathrm{g}}$ & \\
\hline
\end{tabular}

Values in each column represent the mean \pm standard error of three readings. Those marked with different superscripts in each of the column show significant difference at $\mathrm{P} \leq 0.05$ as analyzed by LSD. The mean $\mathrm{Cd}$ analysis is within the row

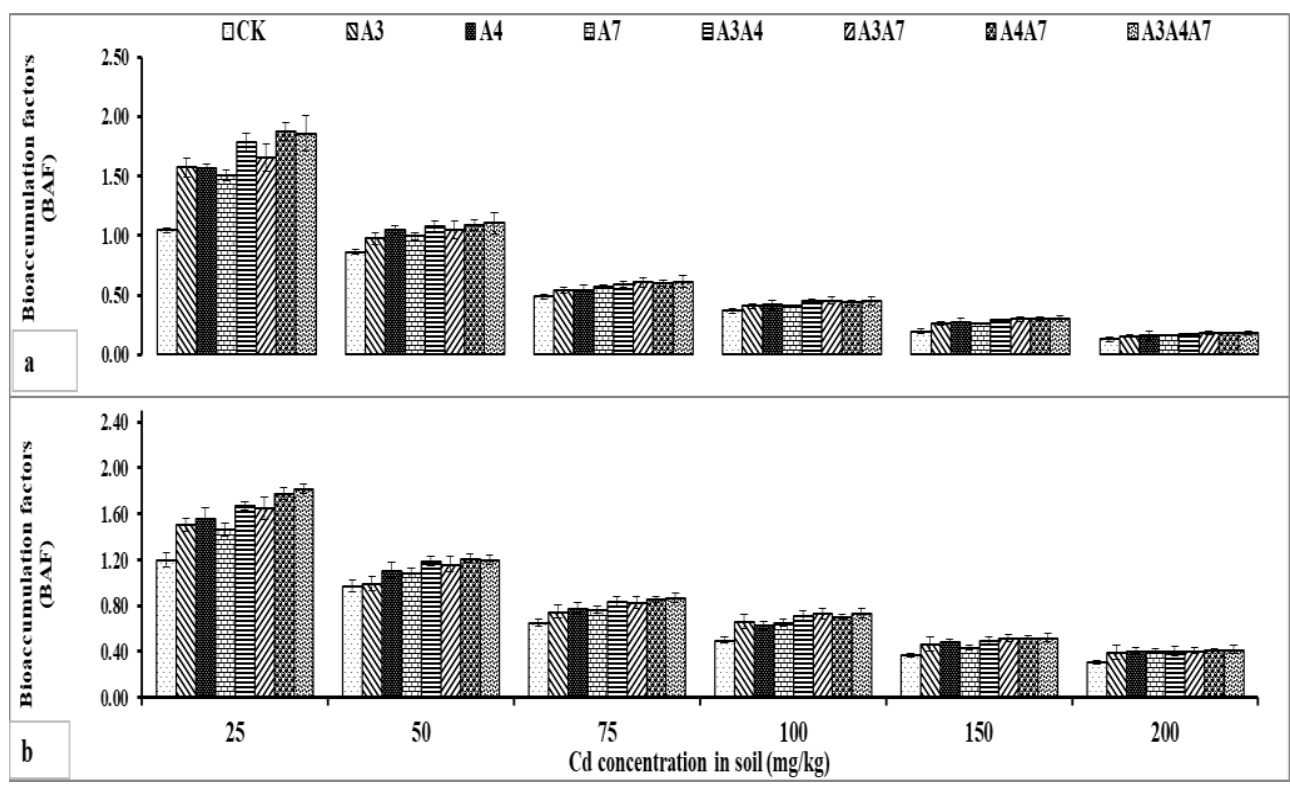

Figure 1. Bioaccumulation factors (BAF) of Cd for (a) shoot and $(b)$ root of $P$. giganteum plants grown on metal contaminated soils and under different bacteria strains and their cocktails with standard error shown as error bars

The root BAF presented in Fig. $1 b$ followed a similar pattern as the shoot BAF, decreasing with increasing $\mathrm{Cd}$ concentration. However, the root $\mathrm{BAF}$ values at the corresponding $\mathrm{Cd}$ treatments were slightly higher than the shoot. All treatments up to 
$50 \mathrm{mg} / \mathrm{kg}$ had values 1.0 and above except the CK (no bacteria application) at $50 \mathrm{mg} / \mathrm{kg}$. Overall, root BAF values were in the range of $0.31(\mathrm{CK}, 200 \mathrm{mg} / \mathrm{kg}$ ) to 1.82 (A4A7, $25 \mathrm{mg} / \mathrm{kg}$ ). BAF values for the treatments with no bacteria inoculation were lowest for all Cd treatments for both shoot and root.

The highest TF values for each of the bacteria treatment was recorded at $25 \mathrm{mg} / \mathrm{kg}$ $\mathrm{Cd}$, however, above $25 \mathrm{mg} / \mathrm{kg} \mathrm{Cd}$, it then decreased progressively with increasing $\mathrm{Cd}$ content in the soil. Overall, the values of $\mathrm{TF}$ were in the range of $0.30(\mathrm{CK}, 0 \mathrm{Cd}$ supplied) to 1.07 (A3A4, $25 \mathrm{mg} / \mathrm{kg}$ Cd supplied) (Figure 2).

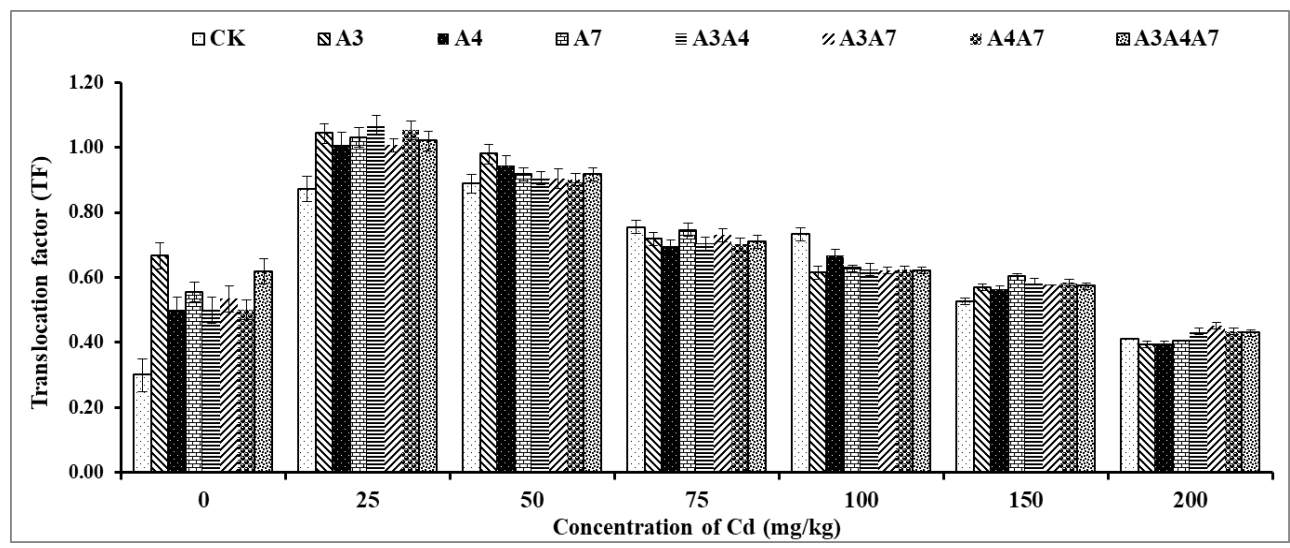

Figure 2. Translocation factor (TF) of Cd for P. giganteum plants grown on metal contaminated soils and under different bacteria strains and their cocktails with standard error shown as error bars

\section{Discussion}

Several studies have enumerated the beneficial effect of PGP rhizobacteria in promoting plant growths under various abiotic stresses whereby the bacteria act as biosorption for soil toxins and assist in the removal of pollutants from the soil (Glick et al., 2007; Glick, 2012; Saxena et al., 2019).

Although single strain inoculations promoted biomass production, the levels were not as high as in double or triple inoculations. As a result, double and triple could be the preferred combinations in $P$. giganteum growth promotion whereby A4A7 and A3A4A7 had the highest values. It could therefore be inferred that the combined traits from each of the bacterium played a considerable role in growth promotion as explained by the additive hypothesis (Bashan and Holguin, 1997). The additive hypothesis explains the synergistic mechanism of PGPB in achieving higher growth and phytoremediation abilities of consortium bacteria application over single strain application. Several studies have shown that Klebsiella pneumonia and Klebsiella sp produce high quantities of plant growth-promoting phytohormones such as IAA and ACC deaminase which may have been responsible for the observed high biomass (Qin et al., 2014).

The exposure of plants to excess levels of $\mathrm{Cd}$ could have inhibited physiologically active enzymes (Gadd, 2007), inactivated photosystems (Ghori et al., 2019; Zhu et al., 2019), affected mineral absorption and metabolism (Janas et al., 2010). Cd toxicity could have severely damaged various metabolic activities in plants leading to reduced height and weight, and leaf chlorosis (Chowdhury et al., 2018). Leaves of plants exposed to moderate to high Cd concentration without PGPB assistance turned yellow 
whereas plants under the $0 \mathrm{mg} / \mathrm{kg} \mathrm{Cd}$ (no Cd added) and soil supplied with low metal concentrations were healthy. This is because, plant Cd uptake is largely influenced by the availability of metals, explaining why higher quantities of metals are absorbed into the root tissues of the plants at higher Cd supplied when the plants were growing well under the assistance of PGPB. However, the content of metals in shoots initially increased then starts decreasing as the concentration of $\mathrm{Cd}$ supplied continued to increase. This is partly because the excess $\mathrm{Cd}$ supplied affected the photosynthetic ability of the plant which in turn reduced the quantity of metals translocated to the shoot of the plant. Plant heights and weights significantly increased at low concentrations of $\mathrm{Cd}$, and then progressively reduced as the quantity of $\mathrm{Cd}$ increased. This observation is in line with the findings of Jadia and Fulekar (2008) and Yang et al. (2018), who showed that low quantities of applied Cd elongated the root and shoot of sunflower but at higher concentrations, significantly reduced germination percentage and plant growth especially root and shoot elongation. Many authors, (Tewari et al., 2002; Zhou and Qiu, 2005; Gajewska and Skłodowska, 2007; Alaboudi et al., 2018) observed that different plant species grown in high Cd contaminated soils showed a visible effect on growth and metabolism and described symptoms including stunted growth, reduced biomass, and yellowing of leaves. Such characteristic effects were observed in the P. giganteum plants grown under the high Cd concentrations without PGPB.

The extraction of heavy metals from soil by plants is usually a slow process. In order to speed up the process, studies have suggested environmentally friendly approaches such as the use of PGPB and their synergistic effects. From our results, the average concentrations of $\mathrm{Cd}$ in shoot of plants inoculated with double strain at 0,25 , and $200 \mathrm{mg} / \mathrm{kg} \mathrm{Cd}$ were significantly higher than those inoculated with single strain by $51.9 \%, 12.9 \%$, and $11 \%$, respectively. Similarly, in roots, the average concentrations of $\mathrm{Cd}$ in the double strain inoculated plants over the single strain inoculated plants were $53.3 \%, 11.3 \%$, and $1.7 \%$ higher, respectively for 0,25 , and $200 \mathrm{mg} / \mathrm{kg} \mathrm{Cd}$. This indicates that a cocktail of the bacterial mixture is better than using single strain culture and their synergistic effect is key in Cd remediation whereby they boost the growth and $\mathrm{Cd}$ absorption by host plants. This is because each strain possesses unique characteristics such as Cd resistance, the synthesis of ACC deaminase enzymes, IAA, and siderophore productions and it could be inferred that the combined effects of these traits produced the observed positive results. For instance, Klebsiella pneumonia produce antioxidants and exhibit strong $\mathrm{Cd}$ tolerance abilities which enable high survival in Cd stressed environment and promote plant growth through the secretion of IAA, ACC deaminase, and other PGP physiological traits (Pramanik et al., 2017). Results from our study correlate the findings of Kang et al. (2016), who reported that the synergistic effect of Viridibacillusarenosi B-21, Sporosarcina soli B-22, Enterobacter cloacae KJ-46, and E. cloacae KJ-47 had better resistance and efficiency in the remediation of $\mathrm{Pb}, \mathrm{Cd}$, and $\mathrm{Cu}$ compared with using single strain culture after $48 \mathrm{~h}$.

Heavy metals such as $\mathrm{Cd}$ are known to inhibit the transport of electron in photosynthetic pathway (Monni et al., 2001). The synthesis of chlorophyll in the plant is also directly inhibited by $\mathrm{Cd}$ through a misstepping of an enzymatic process or by reducing the efficiency of an essential nutrient (Duan et al., 2018). There was significant reduction in chlorophyll content in the leaves of plants in our study as $\mathrm{Cd}$ concentrations increased above $25 \mathrm{mg} / \mathrm{kg}$. At all $\mathrm{Cd}$ concentrations, chlorophyll contents were high in treatments with cocktail bacteria inoculations. Numerous studies have demonstrated that the decrease in photosynthetic rate with an increasing amount of 
Cd may be a result of inhibition of the chlorophyll biosynthesis and the photochemical reactions (Song et al., 2019) as well as the disturbance in the activity of enzymes involved in $\mathrm{CO}_{2}$ fixation (Krantev et al., 2008). However, as evidenced by this study and by other numerous studies (Tak, 2015; Pan et al., 2016; Chiboub et al., 2018), PGPB can improve oxidative stress thereby improving the synthesis of chlorophyll, improve other physiological and biochemical stresses imposed by heavy metals, and improve the adaptability of remediation plants to heavy metal pollution.

According to McGrath and Zhao (2003), the efficiency at which a plant can extract pollutants from the soil is determined by two key factors: biomass production and metal hyperaccumulating capacity. The high biomass production of the $P$. giganteum plant is noted by Zhanxi and Zhanhua (2001) as high as 300 tons (green) material annual yield per hectare is achieved. In terms of metal hyperaccumulating capacity, our study characterized the plant based on the understanding that firstly, for a plant to qualify as a hyperaccumulator of a particular metal, its BAF and TF values should be greater than 1 (Mirza et al., 2010). BAF for both shoot and roots were all > 1 at $25 \mathrm{mg} / \mathrm{kg} \mathrm{Cd}$ supplied even without the contribution of bacteria, indicating that $P$. giganteum could be a suitable hyperaccumulator of $\mathrm{Cd}$ at levels $25 \mathrm{mg} / \mathrm{kg}$. However, to sustain this hyperaccumulative ability up to $50 \mathrm{mg} / \mathrm{kg}$, the plants required the concerted effort of PGPB.

According to our study, TF values at $25 \mathrm{mg} / \mathrm{kg}$ were $>1$ in plants assisted with PGPB. At same Cd concentration of $25 \mathrm{mg} / \mathrm{kg}$, the TF values in plants without PGPB were less than 1, showing the role the bacteria are playing in the plant's hyperaccumulative characteristics. At same Cd concentrations, root BAF were generally higher than shoot BAF indicating that the mobilization and storage of the metal in aerial plant parts is reduced. This observation was also noted by Xue et al. (2013) who also found that $\mathrm{Cd}$ accumulated more in the roots of soybean than in the shoots. $\mathrm{Xu}$ et al. (2018) observed similar findings and asserted that in higher plants, roots are the first organs with contact to $\mathrm{Cd}$, and hence, the roots strongly retain more of the $\mathrm{Cd}$ with just about $2 \%$ of the accumulated Cd translocated to leaves. It is however necessary to note that, the uptake and translocation of metal from roots to shoots is strongly linked to the speciation of the metal in question, the soil $\mathrm{pH}$, and other factors. Since the goal of the phytoremediation process is to reduce heavy metal concentrations in contaminated soil to acceptable levels within a reasonable time frame, high root BAF values are appreciated. Our results agree with the view that plants possessing greater shoot biomass compensate for lower ability to concentrate metals in shoots in phytoextraction techniques (Ebbs et al., 1997).

Overall, even without PGPB assistance, $P$. giganteum is a hyperaccumulator at lower concentrations of $\mathrm{Cd}$. At moderate concentrations, $\mathrm{BAF}$ and $\mathrm{TF}$ values were greater than 1 only with the assistance of PGPB, and at high concentrations, the toxicity effects of the metals on both the plants and the bacteria reduced its metal accumulative capacity. Thus, BAF and TF increase as a function of Cd supplied up to $25 \mathrm{mg} / \mathrm{kg}$, after which the factors start decreasing reaching a low of 0.31 (root) and 0.13 (shoot) for BAF and 0.39 for TF, all at $200 \mathrm{mg} / \mathrm{kg}$. These relationships, as seen in Figures 1 and 2, were also observed by Sabeen et al. (2013) who found the translocation and bioaccumulation factors of Arundo donax L. increased with increasing concentration of Cd up to 500 $\mu \mathrm{g} / \mathrm{g}$, after which it decreased at higher concentration of $\mathrm{Cd}$ in soil.

Biological approaches at remediating polluted lands are catching up with a greenconscious society that is trying hard to reduce the excessive use of chemicals in its 
agricultural and environmental clean up activities. This study is a contribution to knowledge in this direction that seeks to reduce pollution and could be further utilized in the production of biofertilizer for the enhancement of plant growth and remediation of Cd polluted lands.

\section{Conclusion}

The study employed the use of $P$. giganteum in $\mathrm{Cd}$ remediation at different concentrations with the help of three bacteria strains and their combinations. As Cd concentrations progressively increased, plant growth parameters, including plant height, chlorophyll contents, and fresh and dry weights of shoots and roots significantly reduced. However, when the plants were inoculated with PGPB combinations, the measured growth parameters were enhanced. Although significant differences were observed between single and consortium bacteria application, there was no significant difference in growth parameters when either a double or triple consortium was applied. The study also revealed that, as the concentration of the metal increased, the effect differences of either a single, double, or triple strain application became similar. Overall, it has been asserted that high plant biomass can substitute for a relatively low metal accumulation capacity, resulting in the eventual accumulation of a large amount of heavy metal. Therefore, it is recommended that the synergistic abilities of these strains could be utilized in association with $P$. giganteum for $\mathrm{Cd}$ remediation. Many different heavy metals pollute our land and multiple contaminations are often common. A study to understand how Jujuncao in association with bacteria could remediate other heavy metals or their multiple contaminations needs to be undertaken.

Acknowledgments. We wish to thank the staff and students of the China National Engineering Research Center of Juncao Technology, Fujian Agriculture and Forestry University, Fuzhou, China. This research was supported by the Special Fund in Fujian Province for the Development of Science and Technology under the guidance of the Central Committee (2018L3003); and Fujian Agriculture and Forestry University (KFA17633A).

\section{REFERENCES}

[1] Alaboudi, K. A., Ahmed, B., Brodie, G. (2018): Phytoremediation of $\mathrm{Pb}$ and $\mathrm{Cd}$ contaminated soils by using sunflower (Helianthus annuus) plant. - Annals of agricultural sciences 63: 123-127.

[2] Bashan, Y., Holguin, G. (1997): Azospirillum-plant relationships: environmental and physiological advances (1990-1996). - Canadian Journal of Microbiology 43: 103-121.

[3] Bücker-Neto, L., Paiva, A. L. S., Machado, R. D., Arenhart, R. A., Margis-Pinheiro, M. (2017): Interactions between plant hormones and heavy metals responses. - Genetics and molecular biology 40: 373-386.

[4] Chiboub, M., Jebara, S. H., Saadani, O., Fatnassi, I. C., Abdelkerim, S., Jebara, M. (2018): Physiological responses and antioxidant enzyme changes in Sulla coronaria inoculated by cadmium resistant bacteria. - Journal of plant research 131: 99-110.

[5] Chowdhury, R., Ramond, A., O'Keeffe, L. M., Shahzad, S., Kunutsor, S. K., Muka, T., Gregson, J., Willeit, P., Warnakula, S., Khan, H. (2018): Environmental toxic metal contaminants and risk of cardiovascular disease: systematic review and meta-analysis. BMJ 362: k3310. 
[6] Chuanboon, K., Nakorn, P. N., Pannengpetch, S., Laengsri, V., Nuchnoi, P., IsarankuraNa-Ayudhya, C., Isarankura-Na-Ayudhya, P. (2019): Proteomics and bioinformatics analysis reveal potential roles of cadmium-binding proteins in cadmium tolerance and accumulation of Enterobacter cloacae. - PeerJ 7: e6904.

[7] Cui, Y., Wang, Q., Dong, Y., Li, H., Christie, P. (2004): Enhanced uptake of soil Pb and Zn by Indian mustard and winter wheat following combined soil application of elemental sulphur and EDTA. - Plant and Soil 261: 181-188.

[8] Dhungana, S. A., Itoh, K. (2019): Effects of Co-Inoculation of Indole-3-Acetic AcidProducing and-Degrading Bacterial Endophytes on Plant Growth. - Horticulturae 5: 17.

[9] Duan, C., Fang, L., Yang, C., Chen, W., Cui, Y., Li, S. (2018): Reveal the response of enzyme activities to heavy metals through in situ zymography. - Ecotoxicology and environmental safety 156: 106-115.

[10] Ebbs, S., Lasat, M., Brady, D., Cornish, J., Gordon, R., Kochian, L. (1997): Phytoextraction of cadmium and zinc from a contaminated soil. - Journal of Environmental Quality 26: 1424-1430.

[11] Edelstein, M., Ben-Hur, M. (2018): Heavy metals and metalloids: Sources, risks and strategies to reduce their accumulation in horticultural crops. - Scientia Horticulturae 234: 431-444.

[12] Gadd, G. M. (2007): Geomycology: biogeochemical transformations of rocks, minerals, metals and radionuclides by fungi, bioweathering and bioremediation. - Mycological research 111(1): 3-49.

[13] Gajewska, E., Skłodowska, M. (2007): Relations between tocopherol, chlorophyll and lipid peroxides contents in shoots of Ni-treated wheat. - Journal of plant physiology 164: 364-366.

[14] Gamez, R., Cardinale, M., Montes, M., Ramirez, S., Schnell, S., Rodriguez, F. J. M. R. (2019): Screening, plant growth promotion and root colonization pattern of two rhizobacteria (Pseudomonas fluorescens Ps006 and Bacillus amyloliquefaciens Bs006) on banana cv. Williams (Musa acuminata Colla). - Microbiological Research 220: 12-20.

[15] Ghori, N.-H., Ghori, T., Hayat, M., Imadi, S., Gul, A., Altay, V., Ozturk, M. (2019): Heavy metal stress and responses in plants. - International journal of environmental science and technology 16: 1807-1828.

[16] Glick, B., Cheng, Z., Czarny, J., Duan, J. (2007): Promotion of plant growth by ACC deaminase-producing soil bacteria. - Eur J Plant Pathol 119: 329-339.

[17] Glick, B. R. (2012): Plant growth-promoting bacteria: mechanisms and applications. Scientifica 2012: 963401.

[18] González-Mendoza, D., Ceja-Moreno, V., Gold-Bouchot, G., Escobedo-Graciamedrano, R., Del-Rio, M., Valdés-Lozano, D., Zapata-Pérez, O. (2007): The influence of radical architecture on cadmium bioaccumulation in the black mangrove, Avicennia germinans L. - Chemosphere 67: 330-334.

[19] Hall, J. Á. (2002): Cellular mechanisms for heavy metal detoxification and tolerance. Journal of experimental botany 53: 1-11.

[20] Hayat, K., Zhou, Y., Menhas, S., Bundschuh, J., Hayat, S., Ullah, A., Wang, J., Chen, X., Zhang, D., Zhou, P. (2020): Pennisetum giganteum: An emerging salt accumulating/tolerant non-conventional crop for sustainable saline agriculture and simultaneous phytoremediation. - Environmental Pollution 265: 114876.

[21] He, Z.-L., Yang, X.-E. (2007): Role of soil rhizobacteria in phytoremediation of heavy metal contaminated soils. - Journal of Zhejiang University Science B 8: 192-207.

[22] Jadia, C. D., Fulekar, M. H. (2008): Phytoremediation: The application of vermicompost to remove zinc, cadmium, copper, nickel and lead by sunflower plant. - Environmental Engineering \& Management Journal (EEMJ) 7: 547-558.

[23] Janas, K., Zielińska-Tomaszewska, J., Rybaczek, D., Maszewski, J., Posmyk, M., Amarowicz, R., Kosińska, A. (2010): The impact of copper ions on growth, lipid 
peroxidation, and phenolic compound accumulation and localization in lentil (Lens culinaris Medic.) seedlings. - Journal of Plant Physiology 167: 270-276.

[24] Kang, C.-H., Kwon, Y.-J., So, J.-S. (2016): Bioremediation of heavy metals by using bacterial mixtures. - Ecological Engineering 89: 64-69.

[25] Krantev, A., Yordanova, R., Janda, T., Szalai, G., Popova, L. (2008): Treatment with salicylic acid decreases the effect of cadmium on photosynthesis in maize plants. Journal of plant physiology 165: 920-931.

[26] Ladislas, S., El-Mufleh, A., Gérente, C., Chazarenc, F., Andrès, Y., Béchet, B. (2012): Potential of aquatic macrophytes as bioindicators of heavy metal pollution in urban stormwater runoff. - Water, Air, \& Soil Pollution 223: 877-888.

[27] Liphadzi, M., Kirkham, M., Mankin, K., Paulsen, G. (2003): EDTA-assisted heavy-metal uptake by poplar and sunflower grown at a long-term sewage-sludge farm. - Plant and soil 257: 171-182.

[28] Liu, D., Chen, L., Zhu, X., Wang, Y., Xuan, Y., Liu, X., Chen, L., Duan, Y. (2018): Klebsiella pneumoniae SnebYK mediates resistance against Heterodera glycines and promotes soybean growth. - Frontiers in Microbiology 9: 1134.

[29] Mcgrath, S. P., Zhao, F.-J. (2003): Phytoextraction of metals and metalloids from contaminated soils. - Current opinion in biotechnology 14: 277-282.

[30] Mckenzie-Reynolds, P. T. (2018): Investigating beneficial microbes from marsh ecosystems for sustainable agricultural and environmental applications. - Delaware State University.

[31] Mirza, N., Mahmood, Q., Pervez, A., Ahmad, R., Farooq, R., Shah, M. M., Azim, M. R. (2010): Phytoremediation potential of Arundo donax in arsenic-contaminated synthetic wastewater. - Bioresource Technology 101: 5815-5819.

[32] Monni, S., Uhlig, C., Junttila, O., Hansen, E., Hynynen, J. (2001): Chemical composition and ecophysiological responses of Empetrum nigrum to aboveground element application. - Environmental Pollution 112: 417-426.

[33] Padmavathiamma, P. K., Li, L. Y. (2007): Phytoremediation technology: hyperaccumulation metals in plants. - Water, Air, and Soil Pollution 184: 105-126.

[34] Pan, F., Meng, Q., Wang, Q., Luo, S., Chen, B., Khan, K. Y., Yang, X., Feng, Y. (2016): Endophytic bacterium Sphingomonas SaMR12 promotes cadmium accumulation by increasing glutathione biosynthesis in Sedum alfredii Hance. - Chemosphere 154: 358366.

[35] Pramanik, K., Mitra, S., Sarkar, A., Soren, T., Maiti, T. K. (2017): Characterization of cadmium-resistant Klebsiella pneumoniae MCC 3091 promoted rice seedling growth by alleviating phytotoxicity of cadmium. - Environmental Science and Pollution Research 24: 24419-24437.

[36] Pramanik, K., Mitra, S., Sarkar, A., Maiti, T. K. (2018): Alleviation of phytotoxic effects of cadmium on rice seedlings by cadmium resistant PGPR strain Enterobacter aerogenes MCC 3092. - Journal of hazardous materials 351: 317-329.

[37] Qin, S., Zhang, Y.-J., Yuan, B., Xu, P.-Y., Xing, K., Wang, J., Jiang, J.-H. (2014): Isolation of ACC deaminase-producing habitat-adapted symbiotic bacteria associated with halophyte Limonium sinense (Girard) Kuntze and evaluating their plant growthpromoting activity under salt stress. - Plant and soil 374: 753-766.

[38] Rajesh, V., Kumar, A. S. K., Rajesh, N. (2014): Biosorption of cadmium using a novel bacterium isolated from an electronic industry effluent. - Chemical Engineering Journal 235: 176-185.

[39] Rezania, S., Taib, S. M., Din, M. F. M., Dahalan, F. A., Kamyab, H. (2016): Comprehensive review on phytotechnology: heavy metals removal by diverse aquatic plants species from wastewater. - Journal of hazardous materials 318: 587-599.

[40] Sabeen, M., Mahmood, Q., Irshad, M., Fareed, I., Khan, A., Ullah, F., Hussain, J., Hayat, Y., Tabassum, S. (2013): Cadmium phytoremediation by Arundo donax L. from contaminated soil and water. - BioMed research international, doi: 10.1155/2013/324830. 
[41] Sabienë, N., Brazauskienë, D. M., Rimmer, D. (2004): Determination of heavy metal mobile forms by different extraction methods. - Ekologija 1: 36-41.

[42] Sarkar, A., Pramanik, K., Mitra, S., Soren, T., Maiti, T. K. (2018): Enhancement of growth and salt tolerance of rice seedlings by ACC deaminase-producing Burkholderia sp. MTCC 12259. - Journal of plant physiology 231: 434-442.

[43] Saxena, G., Purchase, D., Mulla, S. I., Saratale, G. D., Bharagava, R. N. (2019): Phytoremediation of heavy metal-contaminated sites: eco-environmental concerns, field studies, sustainability issues, and future prospects. - Reviews of Environmental Contamination and Toxicology 249: 71-131.

[44] Singh, O., Labana, S., Pandey, G., Budhiraja, R., Jain, R. (2003): Phytoremediation: an overview of metallic ion decontamination from soil. - Applied microbiology and biotechnology 61: 405-412.

[45] Song, X., Yue, X., Chen, W., Jiang, H., Han, Y., Li, X. (2019): Detection of cadmium risk to the photosynthetic performance of Hybrid Pennisetum. - Frontiers in plant science 10: 798.

[46] Szabó, L., Fodor, L. (2006): Uptake of Microelements by Crops Grown on Heavy MetalAmended Soil. - Communications in soil science and plant analysis 37: 2679-2689.

[47] Tak, H. I. (2015): Modulation of growth, antioxidant system in seedling of mustard under different levels of nickel in adaptive response to metal resistant bacteria. - Frontiers in biology 10: 272-278.

[48] Tang, S., Wilke, B.-M., Huang, C. (1999): The uptake of copper by plants dominantly growing on copper mining spoils along the Yangtze River, the People's Republic of China. - Plant and soil 209: 225-232.

[49] Tewari, R. K., Kumar, P., Sharma, P. N., Bisht, S. S. (2002): Modulation of oxidative stress responsive enzymes by excess cobalt. - Plant Science 162: 381-388.

[50] Turgut, C., Pepe, M. K., Cutright, T. J. (2004): The effect of EDTA and citric acid on phytoremediation of $\mathrm{Cd}, \mathrm{Cr}$, and $\mathrm{Ni}$ from soil using Helianthus annuus. - Environmental pollution 131: 147-154.

[51] Varjani, S., Pandey, A., Upasani, V. N. (2020): Oilfield waste treatment using novel hydrocarbon utilizing bacterial consortium-A microcosm approach. - Science of The Total Environment 745: 141043.

[52] Vervaeke, P., Luyssaert, S., Mertens, J., Meers, E., Tack, F., Lust, N. (2003): Phytoremediation prospects of willow stands on contaminated sediment: a field trial. Environmental pollution 126: 275-282.

[53] Wu, W., Wu, P., Yang, F., Sun, D.-L., Zhang, D.-X., Zhou, Y.-K. (2018): Assessment of heavy metal pollution and human health risks in urban soils around an electronics manufacturing facility. - Science of the Total Environment 630: 53-61.

[54] Xu, Z.-M., Mei, X.-Q., Tan, L., Li, Q.-S., Wang, L.-L., He, B.-Y., Guo, S.-H., Zhou, C., Ye, H.-J. (2018): Low root/shoot (R/S) biomass ratio can be an indicator of low cadmium accumulation in the shoot of Chinese flowering cabbage (Brassica campestris L. ssp. chinensis var. utilis Tsen et Lee) cultivars. - Environmental Science and Pollution Research 25: 36328-36340.

[55] Xue, Z.-C., Gao, H.-Y., Zhang, L.-T. (2013): Effects of cadmium on growth, photosynthetic rate and chlorophyll content in leaves of soybean seedlings. - Biologia Plantarum 57: 587-590.

[56] Yang, L. P., Zhu, J., Wang, P., Zeng, J., Tan, R., Yang, Y. Z., Liu, Z. M. (2018): Effect of $\mathrm{Cd}$ on growth, physiological response, $\mathrm{Cd}$ subcellular distribution and chemical forms of Koelreuteria paniculata. - Ecotoxicology and environmental safety 160: 10-18.

[57] Zhanxi, L., Zhanhua, L. (2001): Juncao technology. - China Agricultural Scientech press, Beijing, 188p.

[58] Zhou, W., Qiu, B. (2005): Effects of cadmium hyperaccumulation on physiological characteristics of Sedum alfredii Hance (Crassulaceae). - Plant Science 169: 737-745. 


$$
-2442 \text { - }
$$

[59] Zhu, Q.-L., Guo, S.-N., Wen, F., Zhang, X.-L., Wang, C.-C., Si, L.-F., Zheng, J.-L., Liu, J. (2019): Transcriptional and physiological responses of Dunaliella salina to cadmium reveals time-dependent turnover of ribosome, photosystem, and ROS-scavenging pathways. - Aquatic Toxicology 207: 153-162. 